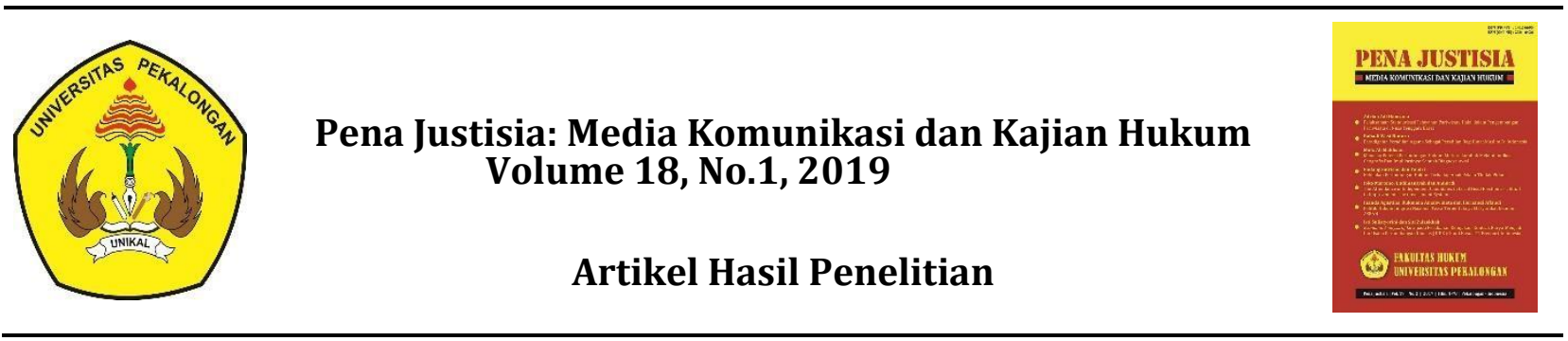

\title{
PENERAPAN TEORI PERLINDUNGAN HUKUM TERHADAP HAK CIPTA ATAS PENYIARAN
}

\author{
Annisa Justisia Tirtakoesoemah, ${ }^{* *}$ Muhammad Rusli Arafat ${ }^{* *}$ \\ **Program Pascasarjana, Fakultas Hukum Universitas Padjadjaran, Email: caesar justitia@hotmail.com \\ **Program Pascasarjana, Fakultas Hukum Universitas Padjadjaran
}

\begin{tabular}{l}
\hline Info Artikel \\
\hline \\
Keywords: \\
Legal Protection, Intellectual \\
Property Rights, Copyright, Legal \\
Entity \\
Kata kunci: \\
Perlindungan Hukum, Hak \\
Kekayaanteletual, Hak \\
Cipta, Badan Hukum
\end{tabular}

\begin{abstract}
Intellectual property rights by nature provide economic benefits to the creator or holder of copyright and also to the state. Among the European countries that are members of the Euroean Union (EU) and in America, this awareness of economic benefits has been firmly planted. In these developed countries, several economic studies have been conducted which have proven the rapid growth of copyright contribution to the national income of the country. The need to recognize, protect and reward individuals or companies for their inventions and access to their work for the benefit of humans is beginning to be felt in Indonesia. In the context of copyright ownership over anything related to intellectual property rights, the law acts and guarantees the creator to control and enjoy exclusively the results of his work and if necessary with the assistance of the state for law enforcement. The results showed that legal protection can be carried out with supervision by the government and involves legal entities that already have the authority, socializing both the creators of a work or the copyright holder of a related rights product on the importance of registering or recording the work and the copyright holder submits lawsuit to the Commercial Court.

\begin{tabular}{l} 
Abstrak \\
\hline Hak kekayaan intelektual pada hakikatnya memberikan manfaat ekonomi \\
kepada pencipta atau pemegang hak cipta dan juga kepada negara. Di \\
kalangan negara-negara eropa yang tergabung di dalam Euroean Union (EU) \\
dan di Amerika, kesadaran akan manfaat ekonomi ini telah tertanam dengan \\
kuat. Di negara-negara maju tersebut beberapa studi ekonomi yang dilakukan \\
telah membuktikan tentang tumbuhnya dengan pesat kontribusi hak cipta \\
terhadap pendapatan nasional negara. Kebutuhan untuk mengakui, \\
melindungi, dan memberi penghargaan terhadap seseorang atau perusahaan \\
atas ciptaanya serta akses atas karya mereka demi kepentingan manusia mulai \\
dirasakan di Indonesia. Dalam hubungan kepemilikan hak cipta atas apa saja \\
yang berkaitan dengan hak kekayaan intelektual, hukum bertindak dan \\
menjamin pencipta untuk menguasai dan menikmati secara eksklusif hasil \\
karyanya itu dan jika perlu dengan bantuan negara untuk penegakan \\
hukumnya. Hasil penelitian menunjukan bahwa Perlindungan hukum dapat \\
dilakukan dengan pengawasan oleh pemerintah dan melibatkan badan \\
hukum yang sudah memiliki wewenang, melakukan sosialisasi baik terhadap \\
para pencipta sebuah karya atau Pemegang hak cipta dari suatu produk hak \\
terkait tentang pentingnya mendaftarkan atau pencatatan ciptaan serta pihak \\
Pemegang hak cipta mengajukan gugatan kepada Pengadilan Niaga.
\end{tabular}
\end{abstract}




\section{PENDAHULUAN}

Hak cipta pada dasarnya merupakan hak eksklusif pencipta yang timbul secara otomatis bedasarkan prinsip deklaratif setelah satu ciptaan diwujudkan dalam bentuk nyata dan tanpa mengurangi pembatasan sesuai dengan ketentuan peraturan perundang-undangan. Dan dapat dikatakan bahwa hak cipta ialah merupakan salah satu kekayan intelektual yang diatur hukum positif nasional dan internasional dapat menimbulkan pertanyaan-pertanyaan siapa yang berbak atas suatu ciptaan dan bagaimana cara memanfaatkan atau mengeksploitasi suatu ciptaan yang dilindungi oleh hukum. ${ }^{1}$ Hak kekayaan intelektual pada hakikatnya memberikan manfaat ekonomi kepada pencipta atau pemegang hak cipta dan juga kepada negara. Di kalangan negara-negara eropa yang tergabung di dalam Euroean Union (EU) dan di Amerika, kesadaran akan manfaat ekonomi ini telah tertanam dengan kuat. Di negara-negara maju tersebut beberapa studi ekonomi yang dilakukan telah membuktikan tentang tumbuhnya dengan pesat kontribusi hak cipta terhadap pendapatan nasional negara. ${ }^{2}$

Pada masa sekarang, sipapun juga menyadari kemajuan teknologi dan informasi, yang telah memberi kontribusi yang demikian besar terhadap globalisasi perdagangan berbagai ciptaan yang telah masuk kedalam unsur Hak Kekayaan Intelektual. berbagai ciptaan Hak Kekayaan Intelektual ini memacu pertambahan permintaan terhadap ciptaan-ciptaan bermutu misalnya ciptaan-ciptaan buku, musik, sinematografi, penyiaran dan program komputer. Kesemua ciptaan ini diperdagangkan secara cepat oleh perusahaan-perusahaan multinasional secara global. Seseorang atau perusahaan mungkin menghabiskan waktu bertahun-tahun untuk mengembangkan suatu hasil karya kreatif yang akan memperkaya kehidupan manusia atau perusahaan tertentu yang bergerak pada bidang Hak Kekayaan Intelektual atau mempunyai unsur Hak Kekayaan Intelektual misalnya (karya sastra, lagu, desain ,program kmputer dan atau penyiaran (television, radio, internet)) jika para pencipta karya tersebut tidak di akui sebagai pencipta atau tidak diberi pengharagaan, atas karya-karya tersebut mungkin tidak akan pernah diciptakan sama sekali. Jika tidak seseorang peduli terhadap ciptaan pencipta karya tersebut, tidak ada seorangpun yang bersedia untuk mencipta suatu ciptaan tadi. Mungkin saja tidak ada insentif pribadi untuk memperoleh pengakuan sebagai pihak yang telah menyumbangkan suatu seni kepada seni sastra atau ilmu pengetahuan. ${ }^{3}$

Kebutuhan untuk mengakui, melindungi, dan memberi penghargaan terhadap seseorang atau perusahaan atas ciptaanya serta akses atas karya mereka demi kepentingan manusia mulai dirasakan di Indonesia. Dalam hubungan kepemilikan hak cipta atas apa saja yang berkaitan dengan hak kekayaan intelektual, hukum bertindak dan menjamin pencipta untuk menguasai dan menikmati secara eksklusif hasil karyanya itu dan jika perlu dengan bantuan negara untuk penegakan hukumnya, hal ini menunjukan bahwa perlindungan hukum merupakan kepentingan hak cipta baik secara individu ataupun kelompok, sebagai subjek hak untuk membatasi mengutamakan kepentingan individu, hukum memberi jaminan tetap terpeliharanya masyarakat. Jaminan ini tercermin dalam sistem HKI yang bekembang dengan menyeimbangkan antara dua kepentingan yaitu kepengtingan pemilik hak cipta dan kebutuhan masyarakat. ${ }^{4}$

Perlindungan hukum atas hak cipta bertujuan untuk melindungi ciptaan-ciptaan dari para pencipta individu atau kelompok yang ingin melakukan suatu tindakan meniru "Plagiat", pada

1 Liana E Susanti, 'Economic Law Creation Beautiful Global Indonesia', Bestuur, 7.1 (2019), 47-53 $<$ https://jurnal.uns.ac.id/bestuur/article/view/42701>.

2 Ahmad Dwi Nuryanto, 'Problem Penyidikan Tindak Pidana Pencucian Uang Yang Berasal Dari Predicate Crime Perbankan', Bestuur, 7.1 (2019), 54 <https://doi.org/10.20961/bestuur.v7i1.43437>.

${ }^{3}$ Sri Mulyani, 'Pengembangan Hak Kekayaan Intelektual Sebagai Collateral (Agunan) Untuk Mendapatkan Kredit Perbankan Di Indonesia', Jurnal Dinamika Hukum, $12.3 \quad$ (2012), 568-78 <https://doi.org/10.20884/1.jdh.2012.12.3.128>.

${ }^{4}$ Khoirul Hidayah and Ulama Hanafiah, 'Kajian Hukum Islam Terhadap Hak Merek', Kajian Hukum Islam Terhadap Hak Merek, 6.1 (2014), 1-9. 
dasarnya hak cipta adalah sejenis kepemilikan pribadi atau perkelompok atau suatu ciptaan yang berupa perwujudan dari suatu ide pencipta di bidang seni, sastra, ilmu pengetahuan. Dikarenakan perlindungan hukum adalah suatu yang sifatnya abstrak, pemerintah sebagai wakil dari masyarakat membuat sesuatu yang lebih kongkrit dalam menegakan dan perlindunga hukum tersebut, yaitu dengan membuat suatu peraturan perundang-undangan. ${ }^{5}$

Dalam industri atau perusahaan, hak cipta yang lahir dari sekelompok orang ini mereka yang bergerak dibidang penyiaran televisi itu dapat di katakan dengan istilah (brodcast television).Penyiaran sendiri memiliki definisi sebagai berikut yakni Penyiaran adalah kegiatan pemancarluasan siaran melalui sarana pemancar atau sarana transmisi di darat, di laut dan di antariksa dengan menggunakan sprektum ferkuensi radio melalui udara, kabel dan media lainya untuk dapat di terima secara serentak dan bersamaan oleh masyarakat dengan perangkat penerimaan siaran. ${ }^{6}$

Khususnya di negara Indonesia penyiaran ini di awasi oleh lembaga penyiaran yakni komisi penyiaran Indonesia, Komisi Penyiaran Indonesia (KPI), memiliki tugas dan wewenang untuk menjaring dan memeriksa suatu siaran yang disiarkan diIndonesia melalui perangkat penyiaran, Komisi Penyiaran Indonesia ini berwenang memeriksa suatu hak cipta di bidang pertelevisian dan perfilman atau penyiaran asing yang masuk kedalam penyiaran di negara Indonesia yang mana patut untuk di siarkan di negara Indonesia ini melalui perangkat penyiaran dan tentu saja memiliki perizinan dari KPI , sebagaimana yang sudah di atur dalam Undang-Undang Nomor 32 tahun 2002 Tentang Penyiaran. ${ }^{7}$

Dewasa ini, kita tahu bahwa perkembangan zaman yang semakin maju dan teknologi pun tidak luput dari perhatian dunia, perkembangan teknologi ini sangatlah pesat meliputi mulai dari media, program-program komputer, alat komunikasi dan informasi, serta media atau alat-alat penyiaran konvensional maupun online, secara khusus teknologi ini untuk mempermudah hubungan atau kepentingan untuk manusia. Berkembangnya teknologi tentang penyiaran ini pun sebenarnya mempunyai dampak buruk bagi para generasi muda mendatang jika dalam bidang penyiaran ini terdapatnya penyiaran yang tidak layak untuk atau tidak patut untuk di pertontonkan entah itu secara konvensional maupun online melalui perangkat penyiaran. ${ }^{8}$

Perkembangan zaman juga menciptakan suatu pengaruh terhadap gaya hidup masyarakat yang semakin kental akan teknologi. Dan dengan hal tersebut juga semakin banyak fasilitas yang memudahkan masyarakat tertentu melakukan pembajakan. Ini sebenarnya menyedihkan bagi para pengusaha atau sekelompok orang yang telah melakukan perjanjian penyiaran swasta dengan penyiaran asing yang sudah memiliki lisensi dan izin namun di ambil atau di siarkan oleh pihak ke lain yang tidak memiliki izin atau lisensi tertentu, tentu saja ini merupakan tindakan pembajakan. Salah satu tindakan pembajakan penyiaran ini terjadi pada PT.Inter Sport Marketing yang merupakan Pemilik Lisensi yang telah bekerjasama dengan FIF $A$ bahwa didalam kesepakatan itu terdapat norma-norma dan hak-hak yang sudah disepakati dan ditunjuk sebagai pemegang Hak Cipta namun mengetahui adanya pelanggaran hak oleh pihak PT.Sun Star Motor mengenai Hak Siar. Berkaca dari kasus tersebut, tulisan ini akan membahasa mengenai berbagai masalah diantaranya Bagaimana perlindungan hukum terhadap hak cipta atas penyiaran penyelengaraaan

${ }^{5}$ Maria Alfons, 'Implementasi Hak Kekayaan Intelektual Dalam Perspektif Negara Hukum', Legislasi Indonesia, 14.03 (2017), 1-10 <http://e-jurnal.peraturan.go.id/index.php/jli/article/view/111/pdf>.

${ }^{6}$ Karlina Sofyarto, 'Perlindungan Hukum Hak Kekayaan Intelektual Atas Pengetahuan Tradisional Terhadap Perolehan Manfaat Ekonomi', Kanun Jurnal Ilmu Hukum, 20.1 (2018), 149-62 $<$ https://doi.org/10.24815/kanun.v20i1.9832>.

${ }^{7}$ V. Selvie Sinaga, 'Faktor-Faktor Penyebab Rendahnya Penggunaan Hak Kekayaan Intelektual Di Kalangan Usaha Kecil Menengah Batik', Jurnal Hukum Ius Quia Iustum, $21.1 \quad$ (2014), 61-80 <https://doi.org/10.20885/iustum.vol21.iss1.art4>.

8 Afifah Kusumadara, 'Pemeliharaan Dan Pelestarian Pengetahuan Tradisional Dan Ekspresi Budaya Tradisional Indonesia: Perlindungan Hak Kekayaan Intelektual Dan Non-Hak Kekayaan Intelektual', Jurnal Hukum Ius Quia Iustum, 18.1 (2011), 20-41 <https://doi.org/10.20885/iustum.vol18.iss1.art2>. 
Piala Dunia FIFA 2014 milik PT. Inter Sport Marketing yang disiarkan oleh PT. Sun Star Motor tanpa lisensi dan izin dari FIFA serta PT.Nonbar dikaitkan dengan Undang-Undang Nomor 28 Tahun 2014 Tentang Hak Cipta? Bagaimana penyelesaian hukum atas pelanggaran hak cipta di bidang penyiaran televisi tentang piala dunia FIFA 2014 yang di selenggarakan oleh PT. Sun Star Motor?

\section{PEMBAHASAN}

Perlindungan Hukum Terhadap Hak Cipta atas Penyiaran Penyelengaraaan Piala Dunia FIFA 2014 Milik PT. Inter Sport Marketing yang Disiarkan oleh PT. Sun Star Motor Tanpa Lisensi dan Izin dari Fifa Serta PT.Nonbar dikaitkan dengan Undang-Undang Nomor 28 Tahun 2014 Tentang Hak Cipta

Ketertiban adalah tujuan pokok dan pertama dari segala hukum.Kebutuhan terhadap ketertiban ini,syarat pokok (fundamental) bagi adanya suatu masyarakat yang teratur.Disamping ketertiban,tujuan lain dari hukum adalah tercapainya keadilan yang berbeda-beda isi dan ukurannya, menurut masyarakat dan zamannya. ${ }^{9}$ Untuk mencapai ketertiban dalam masyarakat ini, diperlukan adanya kepastian dalam pergaulan antarmanusia dalam masyarakat. Hukum merupakan suatu alat untuk memelihara ketertiban dalam masyarakat. Fungsi demikian diperlukan dalam setiap masyarakat, ternasuk yang sedang membangun. ${ }^{10}$

Selain itu, hukum merupakan sarana pembaruan masyarakat yang didasarkan atas anggapan bahwa adanya keteraturan atau ketertiban dalam usaha pembangunan atau pembaruan itu merupakan sesuatu yang diinginkan atau bahkan dipandang (mutlak) perlu. Anggapan lain yang terkandung dalam konsepsi bukum sebagai sarana pembaharuan adalah bahwa hukum dalam arti kaidah atau peraturan hukum memang bisa berfungsi sebagai alat (pengatur) atau sarana pembangunan dalam arti penyalur arah kegiatan manusia ke arah yang dikehendaki oleh pembangunan atau pembaharuan. ${ }^{11}$ Di Indonesia, undang-undang merupakan cara pengaturan hukum yang utama, pembaruan masyarakat dengan jalan hukum berarti pembaruan hukum terutama melalui perundang-undangan. ${ }^{12}$ Perundang-undangan di Indonesia pada umunnya menjamin ketertiban, keadilan dan kepastian hukum serta perlindungan hukum didalam masyarakat. ${ }^{13}$

Menurut Fitzgerald sebagaimana dikutip Satjipto Raharjo awal mula dari munculnya teori perlindungan hukum ini bersumber dari teori hukum alam atau aliran hukum alam. Aliran ini dipelopori oleh Plato, Aristoteles (murid Plato), dan Zeno (pendiri aliran Stoic). Menurut aliran hukum alam menyebutkan bahwa hukum itu bersumber dari Tuhan yang bersifat universal dan abadi, serta antara hukum dan moral tidak boleh dipisahkan. Para penganut aliran ini memandang bahwa hukum dan moral adalah cerminan dan aturan secara internal dan eksternal dari kehidupan manusia yang diwujudkan melalui hukum dan moral. ${ }^{14}$

Menurut Satijipto Raharjo, perlindungan hukum adalah memberikan pengayoman terhadap hak asasi manusia (HAM) yang dirugikan orang lain dan perlindungan itu di berikan kepada masyarakat agar dapat menikmati semua hak-hak yang diberikan oleh hukum. Hukum dapat difungsikan untuk mewujudkan perlindungan yang sifatnya tidak sekedar adaptif dan fleksibel, melainkan juga

\footnotetext{
${ }^{9}$ Luh Inggita Dharmapatni, 'Hak Cipta Sebagai Suatu Objek Jaminan Fidusia', Lex Journal: Kajian Hukum \& Keadilan, $2.2(2018)<$ https://doi.org/10.25139/lex.v2i2.1412>.

${ }^{10}$ Iswi Hariyani, 'Penjaminan Hak Cipta Melalui Skema Gadai Dan Fidusia', Jurnal Hukum IUS QUIA IUSTUM, 23.2 (2016), 294-319 <https://doi.org/10.20885/iustum.vol23.iss2.art7>.

${ }^{11}$ Ibid, hlm. 88.

12 Ibid, hlm. 89.

13 Widya Marthauli Handayani, 'Keberlakuan Hukum Hak Cipta Sebagai Objek Jaminan Fidusia Berdasarkan Undang-Undang Nomor 28 Tahun 2014 Tentang Hak Cipta’, Jurnal Legislasi Indonesia, 16.2 (2019), 214-24.

14 Muhammad Yuris Azmi, 'Nomor 28 Tahun 2014 Tentang Hak Cipta Dan Undang-Undang Tentang Jaminan Fidusia', Universitas Sebelas Maret, IV.1 (2016), 97-106.
} 
prediktif dan antisipatif. Hukum dibutuhkan untuk mereka yang lemah dan belum kuat secara sosial, ekonomi dan politik untuk memperoleh keadilan sosial. ${ }^{15}$

Menurut pendapat Phillipus M. Hadjon bahwa perlindungan hukum bagi rakyat sebagai tindakan pemerintah yang bersifat preventif dan represif. Perlindungan hukum yang preventif bertujuan untuk mencegah terjadinya sengketa, yang mengarahkan tindakan pemerintah bersikap hati-hati dalam pengambilan keputusan bwedasarkan diskresi, dan perlindungan yang represif bertujuan untuk menyelesaikan terjadinya sengketa, termasuk penanganannya di lembaga peradilan. Teori perlindungan hukum merupakan salah satu teori yang sangat penting untuk dikaji, karena fokus kajian teori ini pada perlindungan hukum yang diberikan kepada masyarakat yang berada pada posisi yang lemah,baik secara ekonomis maupun lemah dari aspek yuridis. ${ }^{16}$

Terkait dengan perlindungan HKI, Indonesia sebagai salah satu Negara anggota WTO dan telah memiliki serangkaian undang-undang yang berkaitan dengan HKI. Substansinya secara tertulis telah diadaptasikan dengan standar-standar perlindungan internasional. Perlindungan HKI bukan lagi merupakan kebutuhan domestik suatu negara, tetapi telah menjadi tuntutan secara universal dalam upaya membangun pasar dunia yang harmonis dan dinamis. Tetapi dalam segi implementasinya, kita patut mengkhawatirkanya, melihat supremasi hukum yang belum bisa ditegakkan di Negara kita. $^{17}$

Perlindungan hukum terhadap hak kekayaan pribadi telah menjadi faktor kunci dalam pertumbuhan kapitalisme dan ekonomi pasar bebas. Sejarah merekam dari masyarakat kuno menunjukkanbahwa orang-orang mengakui "hak" untuk men barang, dan dihormati oleh pemerintah untuk melindungi kepentinganmereka dalam kekayaan. Seiring dengan perubahan teknologi konsepsi kekayaan mendapat dampaknya. Sekarang, sistem hukum meletakkan kekayaan ke dalam tiga kategori, yakni: pertama, sebagian besar masyarakat mengakui hak kepemilikan pribadi dalam kekayaan pribadi, yang dikenal dengan in tangible things;.kedua, kekayaan dalam pengertian riil, seperti tanah dan bangunan; dan ketiga, kekayaan yang diketahui sebagai kekayaan intelektual. Semua Negara mengakui hak kekayaan dalam bentuk produk ide, seperti dalam bentuk hak cipta, paten, merek, dan rahasia dagang. ${ }^{18}$

Secara yuridis, penggunaan istilah kekayaan selalu dikaitkan dengan kepemilikan hak atas benda bergerak (moveable goods), benda tidak bergerak (immoveable goods), benda berwujud (tangiblegoods).Dan perspektif hukum kekayaan, hak kekayaan intelektualdigolongkan sebagai hak milik pribadi (personal property) yang timbul dari hak alamiah manusia (natural rights). Karenanya, hak kekayaan intelektual, serupa dengan hak kebendaan lainnya, dapat dipertahankan dari kekuasaan siapapun yang tidak berhak. ${ }^{19}$ Hak kekayaan intelektual ini merupakan hak yang berasal dari hasil kegiatan kreatif suatu kemampuan daya pikir manusia yang diekspresikan kepada khalayak umum dalam berbagai bentuknya, yang memiliki manfaat serta berguna dalam menunjang kehidupan manusia, maksudnya ialah bahwa kepemilikan itu wajar karena sifat ekonomis manusia yang menjadikan hal itu satu keharusan untuk menunjang kehidupannya di dalam masyarakat. ${ }^{20}$ Perlindungan HKI lebih

${ }^{15}$ Nur Adi Kumaladewi, 'Eksekusi Kendaraan Bermotor Sebagai Jaminan Fidusia Yang Berada Pada Pihak Ketiga', Jurnal Repertorium, II.2 (2015), 60-77.

16 C.D. Balenina, 'Partisipasi Masyarakat Dalam Pengelolaan Desa Sampah Mandiri Di Desa Kalisoro,

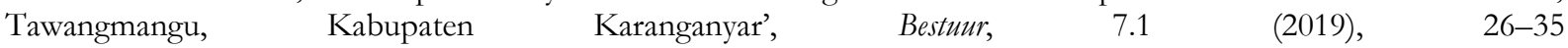
<https://doi.org/https://dx.doi.org/10.20961/bestuur.v7i1.28418>.

${ }^{17}$ Febry Wulandari and W Waluyo, 'Efektivitas Pemanfaatan Dana Bagi Hasil Cukai Hasil Tembakau Dalam Bidang Kesehatan Di Kota Surakarta Tahun 2018', Jurnal Bestuur, 7.1 (2019).

18 Setiati Widihastuti and Eny Kusdarini, 'Kajian Hak Kekayaan Intelektual Karya Perajin Batik', Jurnal Penelitian Humaniora, 18.2 (2013), 145-55.

${ }^{19}$ Sinaga.

${ }^{20}$ Hidayah and Hanafiah. 
dominan pada perlindungan individual, namun untuk menyeimbangkan kepentingan individu dengan kepentingan masyarakat, maka sistem HKI mendasar pada prinsip sebagai berikut: ${ }^{21}$

1. prinsip Keadilan (The Principle Of Natura Justice)

Pencipta sebuah karya, atau orang lain yang bekerja membuahkan hasil dari kemampuan intelektualnya, wajar memperoleh imbalan. Imbalan tersebut dapat berupa materi maupun bukan materi seperti adanya rasa aman karena dilindungi, dan diakui diatas hasil karyanya. Hukum memberikan perlindungan tersebut demi kepentingan pencipta berupa suatu kekuasaan untuk bertindak dalam rangka kepentingan tersebut, yang disebut hak. Setiap hak menurut hukum mempunyai title, yaitu suatu peristiwa tertentu yangmenjadi alasan melekatnya hak itu pada pemiliknya. Menyangkut hak milik intelektual, maka peristiwa yang menjadi alasan melekatnya itu, adalah penciptaan yang mendasarkan atas kemampuan intelektualnya. Perlindungan ini pun tidak sebatas di dalam negeri penemu itu sendiri, melainkan juga dapat meliputi perlindungan di luar batas Negaranya. Hal itu karena hak yang ada pada seseorang ini mewajibkan pihak lain untuk melakukan (commission), atau tidak melakukan (omission) suatu perubahan.

\section{Prinsip Ekonomi (The Economic Argumen)}

Dalam praktik bisnis saat ini, hak kekayaan intelektual telah digolongkan sebagai industri kreatif yang bernilai ekonomis dan digolongkan sebagai suatu komoditas dagang yang menyentuh langsung sistem perekonomian disuatu negara. Para ekonom bisa mengkalkulasikan nilai ekonomis dari hak kekayaan intelektual secara riil dalam bentuk royalti atau good will dan hak ekonomi lainya seperti hak monopoli.

Salah satu HKI yang dilindungi adalah Hak Cipta, dalam Undang-Undang Nomor 28 tahun 2014 Tentang Hak Cipta ciptaan yang di lindungi meliputi 19 point sesuai dengan yang sudah tercantum dalam Pasal 40 Tentang Hak Cipta yaitu :

Ciptaan yang dilindungi :

Pasal 40 :

a. Buku, pamflet, pewajahan karya tulis yang diterbitkan, dan semua hasil karya tulis lainya.

b. Ceramah, kuliah, pidato, dan ciptaan sejenis lainya.

c. Alat peraga untuk kepentingan pendidikan dan ilmu pengetahuan.

d. Lagu dan/atau musik dengan atau tanpa teks.

e. Drama, drama musikal, tari, koreografi, pewayangan, dan pantonim.

f. Karya senirupa dalam segala bentuk lukisan, gambar, ukiran, kaligrafi, seni pahat, patung, atau kolase.

g. Karya seni terapan.

h. Karya arsitektur.

i. Peta.

j. Karya seni batik atau seni motif lain.

k. Karya fotografi.

1. Potret

m. Karya seni sinematografi

n. Terjemahan, tafsir, saduran, bunga rampai, basis data, adaptasi, aransemen, modifikasi, dan karya lain dari transformasi.

o. Terjemahan, adaptasi, aransemen, transformasi, atau modifikasi ekspresi budaya tradisional.

p. Kompilasi ciptaan atau data, baik dalam format yang dapat di baca dengan program komputer atau media lainya.

q. Kompilasi ekspresi budaya tradisional selama kompilasi tersebut merupakan karya yang asli.

${ }^{21} \mathrm{Ni}$ Ketut Supasti, 'Relevansi Hak Kekayaan Intelektual Dengan Hak Asasi Manusia Generasi Kedua', Jurnal Dinamika Hukum, 14.3 (2014), 518-27 <https://doi.org/10.20884/1.jdh.2014.14.3.323>. 
r. Permainan,video, dan

s. Program komputer.

Hak cipta pada dasarnya merupakan hak eksklusif pencipta yang timbul secara otomatis bedasarkan prinsip deklaratif setelah satu ciptaan diwujudkan dalam bentuk nyata dan tanpa mengurangi pembatasan sesuai dengan ketentuan peraturan perundang-undangan. Dan dapat dikatakan bahwa hak cipta ialah merupakan salah satu kekayan intelektual yang diatur hukum positif nasional dan internasional dapat menimbulkan pertanyaan-pertanyaan siapa yang berbak atas suatu ciptaan dan bagaimana cara memanfaatkan atau mengeksploitasi suatu ciptaan yang dilindungi oleh hukum. ${ }^{22}$

Hal ini membuktikan bahwa hak cipta itu merupakan hak yang dapat dimiliki, dapat menjadi obyek pemilikan atau hak milik dan oleh karenanya terhadap hak cipta itu berlaku syarat-syarat kepemilikan, baik mengenai cara penggunaanya maupun cara pengalihan haknya. Semua Undang-Undang akaan memberikan perlindungan sesuai dengan sifat dan hak tersebut. Dapat pula dipahami, bahwa perlindungan yang diberikan oleh UU terhadap hak cipta adalah untuk menstimulir atau merangsang kreatifitas. Lahirnya ciptaan yang baru atau ciptaan yang sudah ada sebelumnya harus didukung dan dilindungi oleh hukum. Wujud perlindungan itu dikukuhkan dalam UU dengan menempatkan sanksi pidana terhadap orang yang melanggar hak cipta dengan cara melawan hukum. Hak Terkait yakni merupakan salah satu dari hak cipta yang mana hak terkait ini adalah hak eksklusif yang berkaitan dengan hak cipta yaitu hak eksklusif bagi Pelaku yang memperbanyak atau menyiarkan pertunjukan; bagi Produser Rekaman Suara untuk memperbanyak atau menyewakan karya rekaman suara atau rekaman bunyinya: dan bagi Lembaga Penyiaran untuk membuat, memperbanyak, atau menyiarkan karya siarannya.

Penyiaran sendiri memiliki definisi sebagai berikut yakni Penyiaran adalah kegiatan pemancarluasan siaran melalui sarana pemancar atau sarana transmisi di darat, di laut dan di antariksa dengan menggunakan sprektum frekuensi radio melalui udara, kabel dan media lainya untuk dapat di terima secara serentak dan bersamaan oleh masyarakat dengan perangkat penerimaan siaran. Sedangkan Hak siar merupakan suatu hak yang diberikan kepada suatu instansi, untuk menyiarkan suatu tayangan tertentu di region atau daerah tertentu yang mana siaran itu disiarkan melalui transmisi di darat, di laut dan di antariksa dengan menggunakan spektrum frekuensi radio melalui udara, kabel dan media lainya. Perlindungan hak siar sudah diatur dalam Undang-Undang Nomor 28 Tahun 2014 Tentang Hak Cipta, perlindungan terhadap Hak siar dibuat untuk melindungi suatu hak atau pemegang hak yang telah di berikan kepada perusahaan atau instansi tersebut, perlindungan ini melindungi pemegang hak cipta yang sudah sepakat untuk memberikan hak nya kepada instansi yang sudah di sepakati sebelumnya, kesepakatan itu merupakan sebuah penerimaan atau sebuah bentuk lisensi ("licensee") dari pihak terkait, jadi lisensi berarti sudah di atur didalam Undang-Undang Nomor 28 Tahun 2014 Tentang Hak Cipta karena perjanjian lisensi ini wajib di daftarkan atau di catatatkan pada Direktorat Jenderal Hak Kekayaan Intelektual. ${ }^{23}$

Dalam Undang-Undang Hak Cipta Indonesia telah diatur tentang penegakan hukum hak cipta yang menetapkan perbuatan apa saja yang disebut sebagai tindak pidana hak cipta dan hak terkait. Demikian pula dalam Undang-Undang Hak Cipta telah diatur tentang tuntutan hak keperdataan yang dapat diajukan dalam bentuk gugatan ke Pengadilan Niaga ataupun bentukbentuk tindakan hukum lainnya yang bertujuan untuk mencegah berlanjutnya suatu pelanggaran hak cipta. Beberapa terobosan di bidang hukum Informasi dan teknologi telah dilakukan untuk mengantisipasi makin meluasnya pelanggaran hak cipta maupun pelanggaran lainya melalui

${ }^{22}$ Winda Risna Yessiningrum and others, 'Perlindungan Hukum Indikasi Geografis Sebagai Bagian Dari Hak Kekayaan Intelektual', 2015, 42-53.

23 Hariyani. 
siaran televisi. Dalam Undang-Undang Hak Cipta sendiri ada beberapa pasal yang mengatur tentang perbuatan pelanggaran hak cipta yang berkaitan dengan perlindungan suatu ciptaan yang menyangkut hak terkait. Sedangkan di luar Undang-Undang Hak Cipta ada Undang-Undang Nomor 32 Tahun 2002 Tentang Penyiaran. ${ }^{24}$

Memperhatikan berbagai kasus pelanggaran hak kekayaan intelektual (HKI) yang terjadi dewasa ini, tersirat bahwa hukum seakan tidak lagi mampu menjadi penghalang atau pencegah terjadinya pelanggaran. Selain motif ekonomi, fenomena ini tampaknya juga dilatar belakangi oleh kemudahan dan keuntungan yang ditawarkan oleh teknologi yang tidak sebanding dengan ancaman hukum yang ditentukan. ${ }^{25}$ Undang-Undang Hak Cipta Nomor 28 tahun 2014 pada Pasal 40 mengatur, ciptaaan yang dilindungi berupa :

Bedasarkan Pasal 40 :

a. Buku, pamflet, pewajahan karya tulis yang diterbitkan, dan semua hasil karya tulis lainya.

b. Ceramah, kuliah, pidato, dan ciptaan sejenis lainya.

c. Alat peraga untuk kepentingan pendidikan dan ilmu pengetahuan.

d. Lagu dan/atau musik dengan atau tanpa teks.

e. Drama, drama musikal, tari, koreografi, pewayangan, dan pantomim.

f. Karya senirupa dalam segala bentuk lukisan, gambar, ukiran, kaligrafi, seni pahat, patung, atau kolase.

g. Karya seni terapan.

h. Karya arsitektur.

i. Peta.

j. Karya seni batik atau seni motif lain.

k. Karya fotografi.

1. Potret

m. Karya seni sinematografi

n. Terjemahan, tafsir, saduran, bunga rampai, basis data, adaptasi, aransemen, modifikasi, dan karya lain dari transformasi.

o. Terjemahan, adaptasi, aransemen, transformasi, atau modifikasi ekspresi budaya tradisional.

p. Kompilasi ciptaan atau data, baik dalam format yang dapat di baca dengan program komputer atau media lainya.

q. Kompilasi ekspresi budaya tradisional selama kompilasi tersebut merupakan karya yang asli.

r. Permainan,video, dan

s. Program komputer.

Selanjutnya pada Pasal 41 UUHC No. 28 Tahun 2014 hasil karya yang tidak dilindungi :

a. Hasil karya yang belum diwujudkan dalam bentuk nyata.

b. Setiap ide, prosedur,sistem, metode, konsep, prinsip, temuan atau data walaupun telah diungkapkan, dinyatakan, digambarkan, dijelaskan, atau digabungkan dalam sebuah ciptaan, dan

c. Alat, benda, atau produk yang diciptakan hanya untuk menyelesaikan masalah teknis atau yang bentuknya hanya ditujukan untuk kebutuhan fungsional.

Kemudian dalam Pasal 54 UUHC No. 28 Tahun 2014 untuk mencegah pelanggaran Hak Cipta dan/atau Hak Terkait melalui sistem elektronik untuk penggunaan secara komersial pemerintah berwenang untuk melakukan ;

${ }^{24}$ I.G.A.K. Rachmi Handayani, Lego Karjoko, and Abdul Kadir Jaelani, 'Model Pelaksanaan Putusan Mahkamah Konstitusi Yang Eksekutabilitas Dalam Pengujian Peraturan Perundang-Undangan Di Indonesia', Bestuur, 7.1 (2019), 36-46 <https://jurnal.uns.ac.id/bestuur/article/view/42700>.

${ }^{25}$ Yessiningrum and others. 
a. Pengawasan terhadap pembuatan dan penyebarluasan konten pelanggaran hak cipta dan hak terkait

b. Kerjasama dan koordinasi dengan berbagai pihak, baik dalam maupun luar negeri dalam pencegahan pembuatan dan penyebarluasan konten pelanggaran hak cipta dan hak terkait.

c. Pengawasan terhadap tindakan perekaman dengan menggunakan media apapun terhadap ciptaan dan produk hak terkait di tempat pertunjukan.

Demikian pula perbuatan PT. Sun Star Motor (SSM) yang telah menyiarkan acara atau pertunjukan siaran piala dunia 2014 FIFA World Cup 2014 tanpa izin dan sepengetahuan dari pihak PT. Inter Sport Marketing (IMS) dan PT. Nonbar merupakan perbuatan melawan hukum sesuai dengan Undang-Undang Hak Cipta Nomor 28 Tahun 2014 karena perbuatan hukum ini telah merugikan beberapa pihak yang memang memiliki hak siar/hak terkait dan lisensi resmi dari FIFA sendiri. ${ }^{26}$

Pada dasarnya pencatatan sebuah karya ini harus di catatkan maupun itu hak cipta atau hak terkait tidak luput juga sebuah karya cipta, dan prosedurnya tercantum dalam Pasal 64 UUHC. No.28 Tahun 2014 dijelaskan bahwa :

(1). Menteri menyelenggarakan pencatatan dan penghapusan ciptaan dan produk hak terkait.

(2). Pencatatan ciptaan dan produk hak terkait sebagaimana dimaksud pada ayat (1) bukan merupakan syarat untuk mendapatkan hak cipta dan hak terkait.

Dalam hal ini yang dimaksud dengan Menteri yang terkait adalah Direktorat Jenderal Hak Kekayan Intelektual yang berada di bawah naungan Menteri Hukum Dan HAM menyelenggarakan pendaftaran hak cipta atau hak terkait dan mencatatnya dalam daftar umum hak cipta, tercantum dalam Pasal 1 angka 26.

Dalam Pasal 66 menjelaskan, ayat:

(1) Pencatatan Ciptaan dan hak terkait diajukan dengan permohonan secara tertulis dalam Bahasa Indonesia oleh Pencipta, Pemegang Hak Cipta, Pemilik Hak Terkait, atau Kuasanya pada Menteri.

(2) Permohonan sebagaimana dimaksud pada ayat (1) dilakukan secara elektronik dan/atau non elektronik dengan :

1. Menyertakan contoh ciptaan, produk hak terkait, atau penggantinya;

2. Melampirkan surat pernyataan kepemilikan dan hak terkait dan:

3. Membayar biaya.

Dalam hal pencatatan atau pendaftaran suatu produk terkait atau Hak terkait yang berupa lisensi (lesence) jika badan atau organisasi internsional mempunyai label yang memang sudah diakui dan merupakan suatu badan pengatur secara internasional serta jika ada suatu penyelenggaraan dari event-event dan mendistribusikan dalam bentuk perjanjian yang dapat disebut dengan pemegang hak cipta, hal ini sudah pasti telah memiliki perjanjian dengan pihak badan hukum dan pemilik resmi atau asosiasi federasi yang merupakan badan pengatur internasional dapat disebut dengan Pencipta atau pemegang Hak Cipta/Hak Terkait. ${ }^{27}$ Selanjutnya, telah disebutkan bahwa hak ekonomi yang diterima oleh pencipta atau pemegang hak cipta seperti yang dijelaskan pada Pasal 9 ayat (1) yaitu:

1. Penerbitan ciptaan;

2. Penggandaan cipta dalam segala bentuknya;

3. Penerjemahan ciptaan;

4. Pengadaptasian, pengaransemenan, atau pentransformasian ciptaan;

\footnotetext{
${ }^{26}$ Pembangunan Ekonomi, 'Konstruksi Konsep Hak Atas Merek Dalam Sistem Hukum Jaminan Fidusia Sebagai Upaya Mendukung Pembangunan Ekonomi’, Masalah-Masalah Hukum, 43.2 (2014), 213-23 <https://doi.org/10.14710/mmh.43.2.2014.213-223>.

${ }_{27}$ Dewi Asri Jayanto and Zainal Asikin, 'Kajian Yuridis Terhadap Merek Sebagai Jaminan Pada Lembaga Perbankan', 32.3 (2017), 508-18.
} 
5. Pendistribusian ciptaan atau salinanya;

6. Pertunjukan ciptaan;

7. Pengumuman ciptaan;

8. Komunikasi ciptaan dan;

9. Penyewa ciptaan.

Lisensi menurut Pasal 1 angka 20 adalah izin tertulis yang diberikan oleh pemegang hak cipta atau pemilik hak terkait kepada pihak lain untuk melaksanakan hak ekonomi atas ciptaanya atau produk hak terkait dengan syarat tertentu. Jika seseorang ingin mendapatkan lisensi dari pemegang hak cipta, maka diwajibkan para pihak untuk membuat sesuatu perjanjian tertulis tentang pemberian lisensi sesuai dengan ketentuan pada Pasal 80 ayat (1) UUHC No. 28 Tahun 2014. Dan jangka waktu berlakunya perjanjian lisensi tersebut adalah dalam waktu tertentu dan tidak melebihi masa berlaku hak cipta atau hak terkait seperti pada Pasal 80 ayat (2). ${ }^{28}$

Dalam perjanjian yang sudah dilakukan pastilah timbul hak dan kewajiban para pihak berupa royalti yang sudah di perjanjikan dan disepakati lalu di berikan kepada pemegang hak cipta dan para pihak yang mendapatkan lisensi tersebut. Pengertian royalti menurut Pasal 1 angka 21 adalah imbalan atas pemanfaatan hak ekonomi suatu ciptaan atau produk hak terkait yang diterima oleh Pencipta atau pemilik Hak terkait, dalam Pasal 80 ayat (3), ayat (4) dan ayat (5) UUHC No. 28 Tahun 2014, pemberian Royalti dilakukan dalam jangka waktu sesuai dengan berlakunya jangka waktu lisensi dan besaran royalti sesuai deengan yang sudah disepakati dalam perjanjian para pihak yang terkait. Pasal 9 ayat (2) Undang-Undang Nomor 28 Tahun 2014 Tentang Hak Cipta mengatur bahwa : "Setiap orang yang melaksanakan hak ekonomi sebagaimana dimaksud pada ayat (1) wajib mendapatkan izin pencipta atau pemegang cipta". ${ }^{29}$

Kemudian, Pasal 9 ayat (3) Undang-Undang Nomor 28 Tahun 2014 Tentang Hak Cipta : "Setiap orang yang tanpa izin pencipta atau pemegang hak cipta dilarang melakukan penggandaan dan/atau penggunaan secara komersial ciptaan". Sesuai dengan Pasal 25 ayat (2) dan ayat (3) Undang-Undang Nomor 28 Tahun 2014 Tentang hak cipta mengatur mengenai :

1. Penyiaran ulang siaran.

2. Komunikasi siaran.

3. Fiksasi siaran; dan/atau.

4. Penggandaan fiksasi siaran.

Pasal 25 ayat (3) Undang-Undang Nomor 28 Tahun 2014 Tentang Hak Cipta: "Setiap orang dilarang melakukan penyebaran tanpa izin dengan tujuan komersial atas konten karya siaran lembaga penyiaran". Adapun yang tercantum pada Pasal 26 huruf d Undang-Undang Nomor 28 Tahun 2014 Tentang Hak Cipta, adanya pembatasan perlindungan tentang penyiaran ketentuan sebagaimana dimaksud dalam Pasal 23, Pasal 24, dan Pasal 25 tidak berlaku terhadap: "penggunaan untuk kepentingan pendidikan dan pengembangan ilmu pengetahuan yang memungkinkan suatu ciptaan dan/atau produk hak terkait dapat digunakan tanpa izin pelaku pertunjukan, produser fonogram, atau lembaga penyiaran".

Dalam studi kasus Putusan Agung Nomor : 517 K/Pdt.Sus-HKI/2015 yang menyangkut PT. Inter Sport Marketing selaku pemegang hak cipta dan memiliki izin resmi serta lisensi resmi dari FIFA dan PT. Nonbar selaku badan hukum yang mengawasi segala aktivitas dari nonton bareng Siaran yang ada di Indonesia. PT. Sun Star Motor telah melakukan penayangan siaran televisi piala dunia Brazil FIFA 2014 dan memasukan logo tidak resmi dalam pagelaran piala dunia Brazil FIFA 2014 tanpa lisensi, tanpa izin dan ilegal demi kepentingan komersial, seharusnya pihak PT. Sun Star Motor ini segera melakukan atau meminta izin terlebh dahulu

28 Azmi.

${ }^{29}$ Djoko Hadi Santoso and Agung - Sujatmiko, 'Royalti Hak Cipta Sebagai Obyek Jaminan Fidusia', Masalah-Masalah Hukum, 46.3 (2018), 198 <https://doi.org/10.14710/mmh.46.3.2017.198-204>. 
kepada Pemegang hak cipta dan pemilik lisensi resmi sesuai dengan Pasal 8 dan Pasal 9 ayat (2) UUHC No. 28 Tahun 2014 yang berkaitan dengan Hak ekonomi atau pemegang hak cipta. ${ }^{30}$

Dalam penggunaan logo sponsor berupa gambar juga telah melanggar Pasal 40 huru $\mathrm{f}$ Undang-Undang Hak Cipta Nomor 28 Tahun 2014, karena Pasal 40 huruf f ini mengatur tentang ciptaan yang dilindungi. Sudah jelas jika memasukan logo yang palsu atau tidak tercantumkan dalam pencatatan hak cipta ini sudah melanggar Pasl 40 huruf f. Pada awalnya pemegang hak cipta PT. Inter Sport Marketing ini meminta itikad baik untuk meminta maaf dan pembayaran dari pihak PT. Sun Star Motor dengan memberikan surat peringatan, namun PT. Sun Star Motor ini tidak memberikan tanggapan, dengan disadari dan melihat tidak adanya itikad baik tersebut pihak pemegang hak cipta mengajukan Gugatan ganti rugi kepada pihak PT. Sun Star Motor yang berkawasan disemarang. ${ }^{31}$

Undang-Undang Nomor 28 Tahun 2014 Tentang Hak Cipta mengatur tentang perlindungan atau ciptaan yang di lindungi sesuai dalam Pasal 40, Jadi sesuai uraian di atas maka seharusnya PT. Sun Star Motor ini segera meminta izin sebelum melanjutkan atau memulai acara siaran televisi mengenai pagelaran piala dunia Brazil FIFA 2014 karena PT. Inter Sport Marketing Sudah memberi surat peringatan maka kewajiban dari PT. Sun Star Motor seharusnya meminta izin secepatnya agar tidak melanggar Undang-Undang Nomor 28 Tahun 2014 Tentang Hak Cipta, berhubung PT. Inter Sport Marketing sudah menggugat PT. Sun Star Motor ke Pengadilan Niaga pada Pengadilan Negeri Semarang maka resiko atau akibat dari perbuatan PT. Sun Star Motor harus di pertanggung jawabkan di Pengadilan Niaga pada Pengadilan Negeri Semarang walaupun PT. Sun Star Motor juga mengajukan kasasi ke Mahkamah Agung dan Mahkamah Agung memutuskan menolak kasasi dari PT. Sun Star Motor.

\section{Penyelesaian Hukum Atas Pelanggaran Hak Cipta di Bidang Penyiaran Televisi Tentang Piala Dunia Brazil FIFA 2014 yang di Selenggarakan oleh PT. Sun Star Motor}

Undang-undang Nomor 28 Tahun 2014 Tentang Hak Cipta telah mengatur tentang perbuatan yang berhubungan dengan penggunaan suatu hak cipta yang digunakan oleh orang lain dalam hak moral dan hak ekonomi dari suatu hak cipta dan hak terkait maupun produk hak terkait. hak ekonomi yang terdapat dalam pencipta atau pemegang hak cipta tercantum dalam Pasal 9 ayat (1) UUHC No. 28 Tahun 2014. Ada perbuatan yang dilarang dilakukan secara tanpa izin dalam praktik penggandaan atau penggunaanya secara komersial. Dalam kasus hak siar oleh PT. Sun Star Motor secara sadar perbuatanya ilegal yang dilakukan tanpa izin dan lisensi resmi dari Pemegang hak cipta, bahwa Pihak PT. Sun Star Motor telah melakukan penyiaran secara langsung atau Live dengan konsep nonton bareng (Nonbar) siaran piala dunia Brazil FIFA 2014 tanpa izin, tanpa lisensi dan dilakukan secara ilegal serta tanpa sepengetahuan dari pihak Pemegang hak cipta atau Pemegang lisensi resmi.

Kronologi dari kasus PT. Sun Star Motor Dan PT. Inter Sport Marketing serta PT. Nonbar yaitu PT. Sun Star Motor menyelenggarakan acara Nonbar siaran piala dunia Brazil FIFA 2014 di diler PT. Sun Star Motor semarang,jalan MT Haryono, pada acara itu menyiarkan pagelaran piala dunia Brazil FIFA 2014 tanpa izin, tanpa lisensi dan dilakukan secara ilegal serta tanpa sepengetahuan dari pihak Pemegang hak cipta atau Pemegang lisensi resmi. Jika ditinjau lebih dalam maka Pemegang hak cipta ini mengalami kerugian secara ekonomi/hak ekonomi dari perbuatan melawan hukum yang dilakukan PT. Sun Star Motor. Dan pihak Pemegang hak cipta PT. Inter Sport Marketing ini dilanggar haknya sesuai dengan Pasal 9 ayat (1) huruf b, $f$ dan huruf $g$ UUHC Nomor 28 Tahun 2014 yaitu penggandaan ciptaan dalam segala bentuknya, pertunjukan ciptaan dan pengumuman ciptaan dan sesuai dengan Pasal 96 ayat (1) dan ayat (2) UUHC Nomor 28 Tahun

\footnotetext{
30 Dharmapatni.
}

31 Handayani. 
2014, Pemegang hak cipta atau Pemegang resmi lisensi itu berhak memperoleh ganti rugi dari PT. Sun Star Motor.

Bedasarkan uraian diatas, sebelum penyelesaian sengketa hukum di pengadilan ada beberapa cara penyelesaian sengketa, dalam Pasal 95 ayat (1) penyelesaian sengketa secara alternatif dan arbitrase. Dalam UUHC No. 28 Tahun 2014 yang dimaksud dengan penyelesaian sengketa secara llternatif yaitu melalui mediasi, negosiasi, dan konsiliasi. Sedangkan yang termasuk dalam sengketa yang terkait yakni perbuatan melawan hukum, perjanjian lisensi. Dapat ditarik simpulan bahwa tindakan PT. Sun Star Motor ini termasuk perbuatan melawan hukum karena tidak meminta izin terlebih dahulu kepada PT. Inter Sport Marketing selaku Pemegang hak cipta dan PT. Nonbar selaku badan hukum Pengawasan Nonbar untuk menggunakan hak siarnya secara komersial serta memasukan logo Mitsubitsi yang tidak resmi hingga seolah-olah masyarakat berasumsi bahwa logo mitsubitsi adalah sponsor resmi dari piala dunia Brazil FIFA 2014.

Dalam kasus ini sebetulnya para pihak bisa menyelesaikan sengketa permasalahan ini dengan baik-baik atau musyawarah dengan segera meminta menghentikan tayangan atau siaran piala dunia Brazil FIFA 2014 yang di adakan di diler PT. Sun Star Motor dan langsung meminta izin dari pemegang hak cipta dan pengawas acara Nonbar yaitu PT. Inter Sport Marketing dan PT. Nonbar. disadari tidak adanya itikad baik dari PT. Sun Star Motor untuk menanggapi surat peringatan yang dilontarkan oleh PT. Inter Sport Marketing, maka pihak Pemegang hak cipta ini mengajukan gugatan kepada pengadilan untuk menyelesaikan kasus tersebut. Dengan cara yang tercantum dalam Pasal 95 ayat (2) bahwa untuk menyelesaikan sengketa hak cipta ini melalui Pengadilan Niaga, dalam hal ini Pengadilan Niaga Semarang. Disamping itu PT. Sun Star Motor tidak menerima putusan dari Pengadilan Niaga Semarang. Maka PT. Sun Star Motor mengajukan kasasi ke Mahkamah Agung karena atas ketidakpuasan dengan putusan Hakim Pengandilan Niaga dengan alasan Pengadilan Niaga semarang telah salah menerapkan hukum. Kemudian Mahkamah Agung memutuskan untuk menolak kasasi yang di ajukan oleh pihak tergugat pada Pengadian Niaga Semarang PT. Sun Star Motor Hasil Putusan Mahkamah Agung, dengan demikian Pada tanggal 30 september 2015 Mahkamah Agung pun memutuskan / Mengadili dari Eksepsi yang di ajukan oleh PT. Sun Star Motor.

Demikianlah diputuskan dalam rapat permusyawaratan majelis hakim pada Mahkamah Agung pada hari Rabu, tanggal 30 September 2015 oleh Syamsul Ma'arif, S.H., LL.M., Ph.D., Hakim Agung yang ditetapkan oleh Ketua Mahkamah Agung sebagai Ketua Majelis, Dr. H. Abdurrahman, S.H., M.H., dan I Gusti Agung Sumanatha, S.H., M.H., Hakim-Hakim Agung, masing-masing sebagai anggota, putusan tersebut diucapkan dalam sidang terbuka untuk umum pada hari itu juga oleh ketua dengan dihadiri oleh anggota-anggota tersebut dan oleh Endang Wahyu Utami, S.H., M.H., Panitera Pengganti tanpa dihadiri oleh para pihak.

\section{PENUTUP}

Berdasarkan hasil penelitian yang dilakukan maka dapat ditarik simpulan, bahwa sebagai berikut: a. Perlindungan hukum yang diberikan pemerintah kepada pencipta sebuah karya atau Pemegang hak cipta merupakan hak ekslusif Pasal 4 Undang-Undang Nomor 28 Tahun 2014 Tentang Hak Cipta dapat dilakukan dengan cara, pertama dengan pengawasan oleh pemerintah dan melibatkan badan hukum yang sudah memiliki wewenang bedasarkan Undang-Undang Nomor 28 Tahun 2014,peran masyarakatpun penting karena masyarakat dapat melaporkan pelanggaranpelanggaran hak cipta atau hak terkait khususnya dalam hak siar sesuai Undang-Undang Nomor 28 Tahun 2014 Tentang Hak Cipta , kedua dengan melakukan sosialisasi baik terhadap para pencipta sebuah karya atau Pemegang hak cipta dari suatu produk hak terkait tentang pentingnya mendaftarkan atau pencatatan ciptaan bedasarkan Pasal 64 ayat (1) Undang-Undang Hak Cipta Nomor 28 Tahun, maupun terhadap masyarakat tentang budaya menghargai dalam bidang hak kekayaan intelektual dapat dilaksanakan dengan baik. b. Upaya hukum yang dilakukan PT. Inter 
Sport Marketing pertama-tama melalui somasi terlebih dahulu akan tetapi karena tidak adanya itikad baik dari PT. Sun Star Motor menanggapi surat peringatan yang dilontarkan oleh PT. Inter Sport Marketing, maka pihak Pemegang hak cipta mengajukan gugatan kepada Pengadilan Niaga dengan cara yang diatur dalam Pasal 95 dan PT. Sun Star Motor wajib membayar ganti rugi kepada Pemegang hak cipta berdasakan Pasal 99 ayat (1) dengan tenggang waktu 6 bulan bedasarkan Pasal 96 ayat (3). Tetapi PT. Sun Star Motor tidak menerima putusan dari PengadilanNegeri Semarang dengan alasan Pengadilan Niaga Semarang telah salah menerapkan hukum maka PT. Sun Star Motor mengajukan kasasi ke Mahkamah Agung dan diputuskan melalui perkara nomor : 517/Pdt.Sus-HKI/2015 dengan menolak permohonan kasasi dari Pemohon, PT. SunStar Motor atas dasar Pengadilan Niaga Semarang tidak salah dalam menerapkan hukum.

\section{REFERENCES}

Alfons, Maria, 'Implementasi Hak Kekayaan Intelektual Dalam Perspektif Negara Hukum', Legislasi Indonesia, $\quad 14.03 \quad$ (2017), $\quad 1-10 \quad<$ http://ejurnal.peraturan.go.id/index.php/jli/article/view/111/pdf>

Azmi, Muhammad Yuris, 'Nomor 28 Tahun 2014 Tentang Hak Cipta Dan Undang-Undang Tentang Jaminan Fidusia', Universitas Sebelas Maret, IV.1 (2016), 97-106

Balenina, C.D., 'Partisipasi Masyarakat Dalam Pengelolaan Desa Sampah Mandiri Di Desa Kalisoro, Tawangmangu, Kabupaten Karanganyar', Bestuur, 7.1 (2019), 26-35 <https://doi.org/https://dx.doi.org/10.20961/bestuur.v7i1.28418>

Dharmapatni, Luh Inggita, 'Hak Cipta Sebagai Suatu Objek Jaminan Fidusia', Lex Journal: Kajian Hukum \& Keadilan, 2.2 (2018) <https://doi.org/10.25139/lex.v2i2.1412>

Ekonomi, Pembangunan, 'Konstruksi Konsep Hak Atas Merek Dalam Sistem Hukum Jaminan Fidusia Sebagai Upaya Mendukung Pembangunan Ekonomi', Masalah-Masalah Hukum, 43.2 (2014), 213-23 < https://doi.org/10.14710/mmh.43.2.2014.213-223>

Handayani, I.G.A.K. Rachmi, Lego Karjoko, and Abdul Kadir Jaelani, 'Model Pelaksanaan Putusan Mahkamah Konstitusi Yang Eksekutabilitas Dalam Pengujian Peraturan PerundangUndangan Di Indonesia', Bestuur, $7.1 \quad$ (2019), 36-46 $<$ https://jurnal.uns.ac.id/bestuur/article/view/42700>

Handayani, Widya Marthauli, 'Keberlakuan Hukum Hak Cipta Sebagai Objek Jaminan Fidusia Berdasarkan Undang-Undang Nomor 28 Tahun 2014 Tentang Hak Cipta', Jurnal Legislasi Indonesia, 16.2 (2019), 214-24

Hariyani, Iswi, 'Penjaminan Hak Cipta Melalui Skema Gadai Dan Fidusia', Jurnal Hukum IUS QUIA IUSTUM, 23.2 (2016), 294-319 < https://doi.org/10.20885/iustum.vol23.iss2.art7>

Hidayah, Khoirul, and Ulama Hanafiah, 'Kajian Hukum Islam Terhadap Hak Merek', Kajian Hukum Islam Terbadap Hak Merek, 6.1 (2014), 1-9

Jayanto, Dewi Asri, and Zainal Asikin, 'Kajian Yuridis Terhadap Merek Sebagai Jaminan Pada Lembaga Perbankan', 32.3 (2017), 508-18

Kumaladewi, Nur Adi, 'Eksekusi Kendaraan Bermotor Sebagai Jaminan Fidusia Yang Berada Pada Pihak Ketiga', Jurnal Repertorium, II.2 (2015), 60-77

Kusumadara, Afifah, 'Pemeliharaan Dan Pelestarian Pengetahuan Tradisional Dan Ekspresi Budaya Tradisional Indonesia: Perlindungan Hak Kekayaan Intelektual Dan Non-Hak Kekayaan Intelektual', Jurnal Hukum Ius Quia Iustum, 18.1 (2011), 20-41 $<$ https://doi.org/10.20885/iustum.vol18.iss1.art2>

Mulyani, Sri, 'Pengembangan Hak Kekayaan Intelektual Sebagai Collateral (Agunan) Untuk Mendapatkan Kredit Perbankan Di Indonesia', Jurnal Dinamika Hukum, 12.3 (2012), 568-78 <https://doi.org/10.20884/1.jdh.2012.12.3.128>

Nuryanto, Ahmad Dwi, 'Problem Penyidikan Tindak Pidana Pencucian Uang Yang Berasal Dari 
$\begin{array}{lllll}\text { Predicate Crime } \quad \text { Perbankan', } & \text { Bestuur, } & 7.1 & \text { (2019), } & 54\end{array}$ $<$ https://doi.org/10.20961/bestuur.v7i1.43437>

Santoso, Djoko Hadi, and Agung - Sujatmiko, 'Royalti Hak Cipta Sebagai Obyek Jaminan Fidusia', Masalah-Masalab Hukum, 46.3 (2018), 198 <https://doi.org/10.14710/mmh.46.3.2017.198204>

Sinaga, V. Selvie, 'Faktor-Faktor Penyebab Rendahnya Penggunaan Hak Kekayaan Intelektual Di Kalangan Usaha Kecil Menengah Batik', Jurnal Hukum Ius Quia Iustum, 21.1 (2014), 61-80 $<$ https://doi.org/10.20885/iustum.vol21.iss1.art4>

Sofyarto, Karlina, 'Perlindungan Hukum Hak Kekayaan Intelektual Atas Pengetahuan Tradisional Terhadap Perolehan Manfaat Ekonomi', Kanun Jurnal Ilmu Hukum, 20.1 (2018), 149-62 $<$ https://doi.org/10.24815/kanun.v20i1.9832>

Supasti, Ni Ketut, 'Relevansi Hak Kekayaan Intelektual Dengan Hak Asasi Manusia Generasi Kedua', Jurnal Dinamika Hukum, $14.3 \quad$ (2014), 518-27 <https://doi.org/10.20884/1.jdh.2014.14.3.323>

Susanti, Liana E, 'Economic Law Creation Beautiful Global Indonesia', Bestuur, 7.1 (2019), 47-53 $<$ https://jurnal.uns.ac.id/bestuur/article/view/42701>

Widihastuti, Setiati, and Eny Kusdarini, 'Kajian Hak Kekayaan Intelektual Karya Perajin Batik', Jurnal Penelitian Humaniora, 18.2 (2013), 145-55

Wulandari, Febry, and W Waluyo, 'Efektivitas Pemanfaatan Dana Bagi Hasil Cukai Hasil Tembakau Dalam Bidang Kesehatan Di Kota Surakarta Tahun 2018', Jurnal Bestuur, 7.1 (2019)

Yessiningrum, Winda Risna, Winda Risna, Yessiningrum Perlindungan, Hukum Indikasi, Geografis Sebagai, and Bagian Dari, 'Perlindungan Hukum Indikasi Geografis Sebagai Bagian Dari Hak Kekayaan Intelektual', 2015, 42-53 